\title{
Predictors of Marital Physical Violence: Personal and Relational Characteristics
}

\author{
Karla Rafaela Haack ${ }^{1}$ \\ Juliana Pressi ${ }^{1}$ \\ Denise Falcke ${ }^{1}$
}

${ }^{1}$ Universidade do Vale do Rio dos Sinos, São Leopoldo, RS

\begin{abstract}
Conjugal violence is a complex phenomenon that deserves attention because of its prevalence. The aim of this study was to verify the predictive power of the family-of-origin experiences, early maladaptive schemas, love, marital adjustment and family climate to marital physical violence occurrence. In this quantitative, correlational and explanatory study 186 men and 186 women took part, aged from 19 to 81 ( $M=41,17$; $S D=12,75)$. The instruments used measured general information, family of origin (FBQ), maladaptive schemes (YSQs), love (TLS), marital adjustment (DAS), family climate (FCI) and marital conflicts (CTS2). The results showed an association between the studied variables. In addition, the variables family conflict and sexual abuse in childhood were predictive of physical violence committed by women, while marital dissatisfaction was the predictor of marital violence committed by men. In view of the results, it can be established that the phenomenon of violence in intimate relationships is multidetermined, requiring attention from health professionals.

Keywords: conjugal physical violence, conjugal relationships, manifestation of violence.
\end{abstract}

\section{Preditores da Violência Física Conjugal: Características Pessoais e Relacionais}

\section{Resumo}

A violência conjugal é um fenômeno complexo que merece atenção pela alta prevalência. O objetivo deste estudo foi verificar o poder preditivo de experiências na família de origem, esquemas iniciais desadaptativos, amor, ajustamento conjugal e clima familiar para a ocorrência de violência física conjugal. Participaram deste estudo, quantitativo, correlacional e explicativo, 186 homens e 186 mulheres, com idades entre 19 a 81 anos $(M=41,17$; $\mathrm{DP}=12,75)$. Os instrumentos utilizados mediram informações gerais, família de origem (FBQ), esquemas desadaptativos (IEDs), amor (ETAS), ajustamento conjugal (DAS), clima familiar (ICF) e conflitos conjugais (CTS2). Os resultados evidenciaram associação entre as variáveis estudadas. Além disso, as variáveis conflito familiar e abuso sexual na infância foram preditoras da violência física cometida pelas mulheres, enquanto que a insatisfação conjugal foi a variável preditora da violência conjugal cometida pelos homens. A partir dos resultados foi possível constatar quanto o fenômeno da violência em relacionamentos íntimos é multideterminado, exigindo atenção dos profisisonais da saúde.

Palavras-chave: violência física conjugal, relacionamentos conjugais, manifestação da violência.

\section{Predictores de Violencia Física Conyugal: Características Personales y relacionales}

\section{Resumen}

La violencia conjugal es un fenómeno complejo que merece atención por su alta prevalencia. El objetivo de este estudio fue verificar el poder predictivo de experiencias en la familia de origen, esquemas iniciales desadaptativos, amor, ajuste conjugal y el clima familiar para la aparición de violencia física conjugal. Participaron deste estudio cuantitativo, correlacional y explicativo 186 hombres y 186 mujeres, con edades entre 19 y 81 años $(M=41,17, S D=12,75)$. Los instrumentos utilizados midieron informaciones generales, familia de origen (FBQ), esquemas desadaptativos (IEDs), amor (ETAS), ajuste conyugal (DAS), clima familiar (ICF) y conflictos conyugales (CTS2). Los resultados mostraron asociación entre las variables estudiadas. Además, las variables conflicto familiar y abuso sexual en la infancia fueron predictores de la violencia física cometida por las mujeres, mientras que la insatisfacción conyugal fue la variable predictora de la violencia conjugal cometida por los hombres. Los resultados muestran que el fenómeno de violencia en relacionamientos íntimos es multi-determinado, requiriendo atención de profesionales de la salud.

Palabras-clave: violencia física conyugal, relaciones maritales, manifestación de violencia.

\section{Introduction}

Domestic violence has been a frequent theme in scientific studies and public policy. To clarify, there is a gender perspective, in which the man is placed in the role of aggressor and the woman is the victim (Miranda, De Paula \& Bordin, 2010; Santos \& Moré, 2011; Gomes, Carvalho, Couto \& Diniz, 2013).
The actions against domestic violence are based primarily on punishing the aggressor and interventions for victim support, such as women's shelters or support groups (Oliveira, 2011). However, the literature has also highlighted the understanding of the phenomenon as capable of occurrence, bidirectionally ie, perpetrated by both the husband and the wife (Langhinrichsen-Rohling, 2010; Straus, 2011 Lovestad \& Krantz, 2012). 
There are studies that show women as the main victims (Leite, Figueiredo, Dias, Vieira \& Mendes, 2014; Santos et al., 2014), others that indicate a symmetry between the sexes (Straus, 2008; Straus, 2011) and even studies that show women perpetrating higher levels than men (Lawrence \& Bradbury, 2007; Williams \& Frieze, 2005).

Among the manifestations of violence, physical violence is in more studies due to its high prevalence in marital relationships (Gama, Bezerra-Filho, Silva, Vieira $\&$ Parente, 2014). It could be understood as any aggression that generates damage to the integrity or health of the subject (Santos et al. 2014), for example, harming their partner with slaps, punches, pushing, use of non-lethal weapons and fire.

Assessing the physical violence from a gender perspective, a study by Moura et al. (2013) analyzed 89 records of women who reported having suffered abuse in a Pacifying Police Unit of Rio de Janeiro. Out of 48 complaints, they found that the perpetrator was the current intimate partner and that physical violence was the prevailing manifestation, in 29 of records, and there were other four in which physical and psychological violence occurred simultaneously. This study was conducted based on formal complaints and that is probably why physical violence was the more recurrent manifestation, since the damage is more noticeable. However, studies on domestic violence often highlight that cases are under reported, considering that many never get to be reported (Falcke, Oliveira, Rosa \& Bentancur, 2009).

The perception of man as a victim of domestic violence is still insignificant in national studies, however, it appears to be getting more attention lately in international studies. Lovestad and Krantz (2012) conducted a cross-sectional population based study with a random sample of 173 swedish men and 251 women, aged between 19 and 65 years and found that $11 \%$ of men compared to $8 \%$ of women had suffered physical violence from the intimate partner in the year preceding the survey. With this, it becomes clear that the victimization data was different from what is commonly expected and known by the society, which brings us to a need for more studies on the role of each partner in the perpetration of domestic violence.

Some variables have been related to the occurrence of domestic violence, such as the experiences in the family of origin (Marasca; Colossi \& Falcke, 2013; Metz \& Razon, 2014), the maladaptive initial regimens (Paim, Madalena \& Falcke, 2012), psychopathologies (Thornton, Graham-Kevan \& Archer, 2010), alcohol consumption and drug use (Oliveira, Lima, Simon,
Cavariani, Tucci \& Corrêa, 2009; Alves \& Diniz, 2005), jealousy (Baptista, 2012; Dias, Machado, Gonçalves \& Manita, 2012) and the dynamics of marital functioning (Dias \& Neves, 2014; Rosa \& Falcke, 2014). The transgenerational perspective states that the experiences in the family (especially, neglect, physical and sexual abuse and caregivers' psychological maladjustment) impact the development of the subject and their future relationships (Silva, Valadares \& Souza, 2013; Baker, Bucher-Maluschke, Almeida \& DeSouza, 2009; Falcke et al, 2009).

Part of this impact can be perceived in the early maladaptive schemes (Young, 2003), acting as rigid, comprehensive and lasting interpretive frameworks that bring functional damage to individuals, especially in interpersonal relationships. In the case of domestic violence, the literature points out the schemes of the first domain as the most associated (Paim, Madalena \& Falcke, 2012).

Beyond the early experiences, the characteristics of the current relationship, especially the patterns of affection, have been considered predictors of violence. Researches show that love is an important component in the marital relationship and is strongly connected to the resources that a couple has to resolve their conflicts (Narciso \& Costa, 1996). Assessed from the combinations of passion, intimacy and decision/commitment (Stenberg, 1989), love contributes to the satisfaction or dissatisfaction in relationships. The literature suggests association between marital dissatisfaction and manifestations of violence in romantic relationships (Razera, Mosmann, \& Falcke, 2016), raising the need to evaluate different dimensions of the family atmosphere in the contexts permeated by violence.

In this sense, it is clear that violence must be understood through its multitude of factors, such as biological, emotional, social, cognitive, behavioral and familial, not as if there was a single generator. However, there is the need to identify predictors of domestic violence, planning preventive interventions of its occurrence. On the impact and consequences of the phenomenon of physical violence exercised in the context of individual and collective health, one realizes the importance of developing research on the subject (Bhona, Lourenço \& Brum, 2011).

The objective of this study was to assess the predictive power of the experiences in the family of origin, maladaptive initial regimens, love, marital adjustment and family atmosphere for the occurrence of physical violence. Thus offering subsidies for recognizing 
violence and helping to train professionals who work in caring for victims of violence and managing interventions with couples.

\section{Method}

\section{Participants}

This quantitative study with a correlational and explanatory design, had 372 subjects, 186 men and 186 women, residents of the metropolitan area of Porto Alegre. The participants were selected by convenience sampling in a process of "snowball". This process uses the relations between the members of the population to reach, from the statement of some of them, a sampleit (Dewes, 2013).

All participants were either officially married or cohabited in a relationship lasting between one and 56 years $(M=15.76, S D=12.06)$. The age of the participants ranged from 19 to 81 years $(\mathrm{M}=41.17, \mathrm{SD}=$ 12.75), most were employed and had children. table 1 has the demographic characteristics of the sample.

\section{Instruments}

The following instruments were used to achieve the proposed objectives:

- Socio-Demographic Data Questionnaire: with 19 questions to gather information such as age, education levels, income, relationship time and others.
- Subscales of the Family Background Questionnaire - FBQ (Melchert, 1998): self-administered questionnaire with 179 questions to be answered in a Likert scale of five points. It has 15 subscales to assess the subject's memories on the experiences in the family of origin. For this study, we used the subscales corresponding to domestic violence experiences and parental mental health, which the literature indicates as possible predictors of marital violence (Marasca, Colossi \& Falcke, 2013; Falcke, 2003). Namely: physical neglect, maternal and paternal physical abuse, sexual abuse, maternal and paternal substance abuse, maternal and paternal psychological adjustment and parental alliance, which correspond to 62 items (Melchert 1998). Physical negligence is the lack of physical care, such as food, clothing and hygiene. Paternal and maternal physical abuse investigates a dysfunctional continuum that includes physical violence and abuse. Sexual abuse is the sexual act or game in which the offender is at a more advanced psychosexual development phase than the victim, assessing from acts where there is no physical contact (such as voyeurism, exhibitionism) to abuse with or without penetration. Paternal and maternal substance abuse measures the presence or absence of alcohol or drugs by the parents and the degree of abuse. The psychological adjustment evaluates the mental health of parents, specifically mood disorders and substance abuse. Finally, parental alliance

Table 1

Frequence and valid percentages of the socio-demographic characteristics of the sample $(n=372)$.

\begin{tabular}{lccccc}
\hline \multirow{2}{*}{ Characteristics } & & \multicolumn{2}{c}{ Men } & Women \\
\cline { 3 - 6 } Conjugal status & Officially & $\mathrm{N}$ & $\%$ & $\mathrm{~N}$ & $\%$ \\
& married & 104 & 57.1 & 102 & 56.4 \\
& Living together & & 48.9 & 79 & 43.6 \\
Previous marriage & Yes & 45 & & & \\
& No & 140 & 75.3 & 30 & 16.4 \\
Children & Yes & 118 & 64.1 & 153 & 83.6 \\
& No & 66 & 35.9 & 118 & 63.4 \\
Education & K-12 & 18 & 10.5 & 68 & 36.6 \\
& High school & 82 & 47.7 & 12 & 6.8 \\
& Superior & 72 & 41.9 & 101 & 35.8 \\
Employed & Yes & 159 & 87.8 & 146 & 57.4 \\
& No & 22 & 12.2 & 32 & 82 \\
\hline
\end{tabular}


is the degree of agreement between the father and the mother regarding the rules or instructions to children as well as the evaluation of the marital relationship. The scores are listed so that the highest indicates a better level of family functioning. The scale was translated into Portuguese and obtained good reliability of 0.99 for the total scale (Falcke, 2003). The alphas obtained in this study were: physical neglect (0.78), maternal physical abuse (0.80) and paternal (0.86), sexual abuse (0.29), maternal substance abuse (0.88) and paternal (0.94), maternal psychological adjustment (0.74) and paternal (0.78) and parental alliance (0.86). The alpha of sexual abuse is low, as it investigates different people as perpetrators (father, mother, brothers, relatives, strangers).

- Young Maladaptive Schema Questionnaire YSQ (Young, 2003): It consists of 90 items that assess 18 initial maladaptive regimens, mapped by the sum of each group of five questions. For this research, will only be used the first domain schemes, Disconnection and Rejection, indicated in the literature as the most associated with domestic violence (Calvete, Estévez and Corral, 2007; Crawford \& Wright, 2007; Khosravi, Attari \& Rezai, 2011) which is characterized by failure in forming secure attachments and with early negative social experiences. There are five schemes to that domain. 1. Abandonment/Instability: Seeing the relationships as unstable and untrustworthy. Feeling that important people abandon them; 2- Distrust/Abuse: The expectation that others will hurt, abuse, humiliate, cheat, lie, manipulate or take advantage. Perceiveing relations as dangerous; 3- Emotional Deprivation: Believing that the other does not adequately satisfy their desire for emotional support; 4- Defectiveness/Shame: Feeling of being defective, unwanted and therefore not worthy of the love of others; 5Social Isolation/Alienation: Feeling of being isolated from others and from the world, feels different from others and/or that they are not part of any group or community (Young, 2003). It has been translated and validated for Portuguese by Rijo and Pinto-Gouveia (1999). Cronbach's alpha of the first domain was 0.96 in this study.

- Triangular Love Scale - TLS (Sternberg, 1989): evaluates the subject's perception of its loving relationship, the intimate dimensions, passion and decision/commitment. It consists of 45 statements that should be answered in a Likert scale ranging from one (not at all) to nine (extremely), (Sternberg, 1989). Intimacy is constituted by the feeling of closeness and connection in the relationship. Passion is the component that governs the physical and sexual attraction, responsible for the romance, desire to be together and the excitement. Decision/Commitment concerns being sure of loving and being loved and the desire to maintain the relationship in long term (Cassepp-Borges \& Teodoro, 2007). We used the Brazilian version of the scale (Cassepp-Borges \& Teodoro, 2007) that has a higher Cronbach's alpha coefficient of 0.90 (intimacy $=0.94$, passion $=0.93$; decision $/$ commitment $=0.96)$. This study's alphas were: intimacy (0.93), passion (0.93) and decision/commitment (0.93).

- Dyadic Adjustment Scale - DAS (Spanier, 1976): 32 items (in which 30 are Likert scale of 6 points and 2 have answers yes or no). Investigates the perception of the relationship, assessing four dimensions: consensus, satisfaction, cohesion and expression of affection. The consensus refers to the individual perception to aspects of the relationship and the level of agreement of the couple on several basic questions such as leisure, finances, friendships, goals, objectives, and others. Satisfaction measures the individual perceptions about possibility of divorce/separation, welfare, trust, regret, happiness, commitment and others. Cohesion measures the degree of emotional sharing and the individual perceptions on mutual engagement such as joint work and projects, ideas, discussions, and more. Finally, the expression of affection, concerns the perception of agreement of the couple on displays of affection and sex (Spanier, 1976). The scale of this study, presented Cronbach's alpha $=0.92$.

- Inventory of Family Climate - FCI (Teodoro, Land \& Allgayer, 2009): self report instrument consisting of 22 questions in Likert five-point scale (ranging from "disagree" to "strongly agree"). Scrutinizes cohesion, support, hierarchy and family conflict. Family cohesion is defined as the emotional bond among family members. Support has items describing the material and emotional support of the members. Hierarchy refers to a clear division of power within the family, in which the older members have more influence on family decisions. Finally, family conflict measures the 
aggressive relationship, criticism and conflict between family members. Psychometric results point to a factor composition compatible with the model of four factors and Cronbach alphas above .80 (Teodoro, Land \& Allgayer, 2009). The alphas in this study were: support (0.71), cohesion $(0.80)$, hierarchy (0.69), conflict (0.85).

- Revised Conflict Tactics Scales - CTS2 (Straus et al., 1996): 78 items that assess the respondent's possible actions and, conversely, of their partner on the following dimensions: 1) physical violence; 2) psychological aggression; 3) sexual coercion; 4) physical injury; 5) negotiating. For this study, only the physical violence measure was used. Straus $(2008,1990)$ categorized it in two types (lesser physical violence and severe physical violence) which will be added making it "total physical violence". The smallest physical violences consist of pushing, grabbing, slapping, throwing objects, twisting the arm and hair-pulling. Severe physical violence is to punch, hit the partner, kick, hitting against a wall, burning or scalding, using a knife or gun (Straus, 1996; 1990). The questionnaire filled by the respondent, was translated into Portuguese by Moraes, Hasselmann and Reichenheim (2002). The internal consistency scores obtained in this study to physical violence subscale was 0.84 .

\section{Procedures for collection and analysis of data}

This study was approved by the Ethics Committee at Unisinos (Protocol 11/129) was in compliance with the provisions of Resolution n. 466/2012 on Researches Involving Human Subjects of the National Health Council (CNS, 2012). The instruments were applied individually in the presence of one of the researchers, at the participant's residence or at a local suggested by them, with an average session duration of two hours. First the research procedures were explained to the participants and they signed the Free and Informed Consent Form.

The data were treated confidentially and anonymously. We used SPSS to perform the analysis of the data. For this we verified the profile of the participants, and Pearson's correlation to check association between continuous variables of physical violence and experiences in the family, family atmosphere, love, schemes and adjustment and marital quality.

Still, to identify predictors of physical violence, we used regression analysis with the stepwise method.
There were two models for the regression (male and female) by inserting the continuous variables that correlated with physical violence perpetrated (dependent variable). Thus the female model included the following independent variables: maternal physical abuse, sexual abuse, maternal psychological adjustment and parental coalition (FBQ), emotional deprivation, mistrust/abuse, social isolation and defectiveness (YSQ), intimacy (TLS), consensus satisfaction and affection (DAS), hierarchy and conflict (FCI). For the male model, the independent variables were: fatherly physical abuse and fatherly psychological adjustment (FBQ), emotional deprivation, abandonment, mistrust/abuse, social isolation and defectiveness (YQS), intimacy and decision/commitment (TLS), consensus, satisfaction and affection (DAS), hierarchy and conflict (FCI).

\section{Results}

The purpose of this study was to assess the predictive power of experiences in the family of origin, maladaptive initial regimens, love, marital adjustment and family atmosphere for the occurrence of physical violence. The results revealed that physical violence was committed by $26.6 \%$ of male participants and $23.1 \%$ of women, as seen in the chart below:

There were no significant statistical differences between the sexes for the perpetration of physical violence $\left(\chi^{2}=0.582, \mathrm{df}=1, \mathrm{p}=0.446\right)$. Even comparisons considering the intensity of violence, made with the continuous variable showed no differences between sexes (minor physical violence: $\mathrm{t}=0.463, \mathrm{p}=0.643$; severe physical violence: $\mathrm{t}=-0.358, \mathrm{p}=0.721$ ).

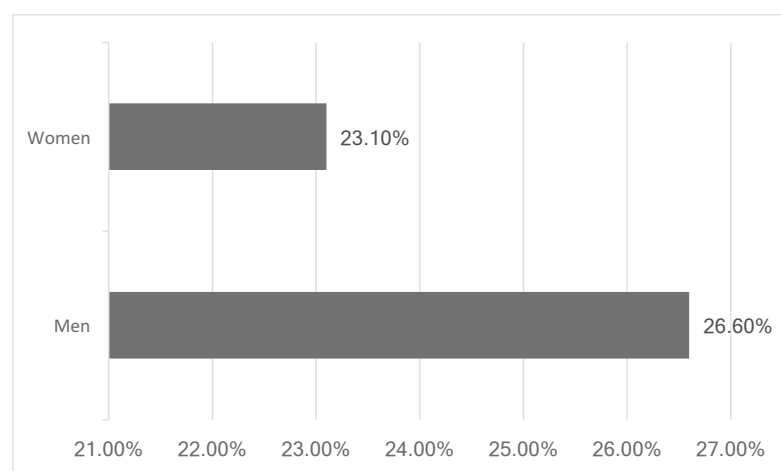

Figure 1 Physical violence occurrence percentage according to gender. 
Table 2

Correlations between physical violence perpetrated by men and women

\begin{tabular}{|c|c|c|c|}
\hline Instrument & Dimensions & Women & Men \\
\hline \multirow[t]{9}{*}{ FBQ } & Physical abuse (father) & -.114 & $-.200^{* *}$ \\
\hline & Physical abuse (mother) & $-.166^{*}$ & -.150 \\
\hline & Sexual abuse & $.258^{* *}$ & .147 \\
\hline & Physical negligence & .009 & $-.175^{*}$ \\
\hline & Substance abuse (father) & .034 & -.085 \\
\hline & Substance abuse (mother) & -.173 & -.030 \\
\hline & Psychological adjustment (father) & -.174 & $-.307^{* *}$ \\
\hline & Psychological adjustment (mother) & $-.220^{* *}$ & -.164 \\
\hline & Parental coalition & $-.233^{* *}$ & -.012 \\
\hline \multirow[t]{5}{*}{ YSQ } & Emotional deprivation & $.268^{* *}$ & $.323^{* *}$ \\
\hline & Abandonment & .137 & $.293^{* *}$ \\
\hline & Mistrust/abuse & $.328^{* *}$ & $.239^{* *}$ \\
\hline & Social isolation & $.232^{* *}$ & $.337^{* *}$ \\
\hline & Deffectiveness & $.341^{* *}$ & $.488^{* *}$ \\
\hline \multirow[t]{3}{*}{ TLS } & Intimacy & $-.173^{*}$ & $-.228^{* *}$ \\
\hline & Passion & -.048 & -.070 \\
\hline & Commitment decision & -.101 & $-.268^{* *}$ \\
\hline \multirow[t]{4}{*}{ DAS } & Consensus & $-.231^{* *}$ & $-.257^{* *}$ \\
\hline & Satisfaction & $-.389^{* *}$ & $-.465^{* *}$ \\
\hline & Cohesion & -.116 & -.112 \\
\hline & Affection & $-.237^{* *}$ & $-.178^{*}$ \\
\hline \multirow[t]{4}{*}{ FCI } & Support & -.035 & -.039 \\
\hline & Hierarchy & $.371^{* *}$ & $.257^{* *}$ \\
\hline & Cohesion & -.073 & -.093 \\
\hline & Conflict & $.362^{* *}$ & $.437^{* *}$ \\
\hline
\end{tabular}

$* \mathrm{p}<0.05 * * \mathrm{p}<0.001$

The correlations between the variables family of origin, schemes, love, marital adjustment and family atmosphere with physical violence perpetrated by men and women are shown in Table 2. Various correlations can be seen, drawing special attention to the experiences in the family of origin, the dimensions of physical abuse suffered in childhood and parental psychological adjustment which clearly show a gender correspondence. Physical abuse and maternal psychological adjustment was associated to the experience of women as the physical abuse and fatherly psychological adjustment were associated with violence committed by men. In addition, all of the first schemes were associated with physical violence. On love, the amount of
Passion was the only one which did not associate with violence, as well as cohesion of marital adjustment and support of the family atmosphere.

Considering the various correlations presented above, we sought to analyze the predictive power of the variables through a regression analysis, which showed the conflict (FCI) and sexual abuse (FBQ) as predictors of physical violence committed by women, as shown below in figure 2 . The procedure provided a variance explained coefficient $\left(\mathrm{R}^{2}\right)$ of 0.582 which shows that these variables explain $58.2 \%$ of the occurrence of physical violence.

In addition, a regression analysis showed the marital satisfaction (DAS) as a predictor of physical violence 
Variables predicting physical violence committed by women

\begin{tabular}{cccccc}
\hline \multicolumn{2}{c}{ Not standardized coefficients } & \multicolumn{3}{c}{ Standardized coefficients } \\
\hline $\begin{array}{c}\text { Model } \\
\text { variables }\end{array}$ & $\mathrm{B}$ & $\begin{array}{c}\text { Standard } \\
\text { Model }\end{array}$ & Beta & $\mathrm{T}$ & Sig \\
\hline $\begin{array}{c}\text { Conflict } \\
\text { Sexual }\end{array}$ & .363 & .061 & .656 & 5.995 & .000 \\
Abuse & 1.469 & .548 & .293 & 2.680 & .011 \\
$\mathrm{R}=0.763 \mathrm{R}^{2}=0.582 \mathrm{R}^{2}$ adjusted $=0.559$ & & & \\
\end{tabular}

Variables predicting physical violence committed by men

\begin{tabular}{cccccc}
\hline \multicolumn{2}{c}{ Not standardized coefficients } & \multicolumn{3}{c}{ Standardized coefficients } \\
\hline $\begin{array}{c}\text { Model } \\
\text { variables }\end{array}$ & $\mathrm{B}$ & $\begin{array}{c}\text { Standard } \\
\text { Model }\end{array}$ & Beta & $\mathrm{T}$ & Sig \\
\hline Satisfaction & -.264 & .062 & -.600 & -4.243 & .000 \\
\hline $\mathrm{R}=0.600 \mathrm{R}^{2}=0.360 \mathrm{R}^{2}$ adjusted $=0.340$ & & &
\end{tabular}

Figure 2 Variables predicting physical violence by men and women

committed by men (Figure 2). With a coefficient of variance explained $\left(\mathrm{R}^{2}\right)$ of 0.360 which determines that it explains $36 \%$ of the physical violence.

These models highlight which variables, among all the examined, had a higher power to predict violence. They showed that the violence perpetrated by the wife could be predicted by the sexual abuse suffered in childhood and the perception of conflict in family relationships, while for men, it was related to marital dissatisfaction.

\section{Discussion}

The results support the view that transgenerational aspects involved in the life history, the individual development and the subjectivity of the spouses are triggering factors of physical violence (Silva, Valadares \& Souza, 2013; Barreto, Bucher-Maluschke, Almeida, \& DeSouza, 2009; Falcke et al., 2009). The primary relationships, especially those experienced in the family of origin, are fundamental to a person's constitution and their interpersonal pattern in adulthood (Marasca, Colossi \& Falcke, 2013; Lopes, 2008; Metz \& Razon, 2014).

Abusive experiences in the childhood were associated with maintaining violent marital relationships. One might think that the choice of partner and the type of relationship established with them can be influenced by the relationship model experienced in both families of origin (Mendlowicz \& Figueira, 2007), serving as a way of repeating a known pattern.
Among the experiences in the family of origin that have more impact on domestic violence, this study specifically highlights the impact of sexual abuse for women as an experience that needs to be analyzed for its long-term impact on their lives. Experiences of abuse in childhood can contribute to the development of Early Maladaptive Schemas - YSQ (Young, 2003). In this study, all the schemes of the first domain have been associated with perpetration of spousal abuse, corroborating previous studies (Paim, Madalena \& Falcke, 2012).

Disconnection and Rejection, the first domain schemes are linked to the lack of a secure and stable environment in childhood, which causes people who grew up in these environments to believe that their stability needs, safety, care, love and belonging will not be met, and it's common that they have negative social experiences such as abuse, coldness, rejection or social isolation (Young, 2003). In this sense, the association between the activation of these schemes and the perpetration of physical violence is confirmed. Couples with dysfunctional schemas often feel more attracted to partners that enable a nuclear scheme, being known "schema chemistry", leading to dysfunctional relationships (Young 2003; Young, Klosko, \& Weishaar, 2008). In addition to the early experiences, these findings extend the discussion on the variables that can explain the phenomenon of domestic violence, strengthening the importance of assessing other experiences related to the marital dynamics in a situation of domestic violence. 
Couples with violent interactions commonly justify not separating saying it's because they love very much (Blay, 2003; Grossi, 1998). This finding is contradicted in this study, which showed no association between passion and the perpetration of spousal abuse. One may question, in this case, what would be the subjective evaluation of passion for these couples, which may differ from the construct measured by the instrument.

Considering the other dimensions of love proposed by Stenberg (1989), the results indicate that the higher the perpetration of violence by spouses, the lower is the perception of intimacy. Even with men, the greater the commitment to the relationship, the lower the use of violence. One can think in this sense that violence generates emotional distancing in the relationship and can compromise the perception of commitment to the future of the relationship.

In regard to how the couple operates, the literature suggests that couples with low marital adjustment levels can adopt violent strategies to resolve their conflicts (DeMaris, 2000; Williams \& Frieze, 2005). The survey results show that the greater the consensus and satisfaction with the relationship, the lowest is the occurrence of physical violence, which is consistent with other researches (Lauer, Lauer \& Kerr, 1990; Notarius \& Markman, 1993; Gottman, 1994 ) that emphasize the importance of couples having consensus on many issues, being valued, being committed to the partner and the relationship, having sense of humor, having goals and life projects in common.

The family atmosphere, defined as how family members perceive various features of the relationship inside the family, is how the relationships within the family are evaluated and understood (Teodoro et al, 2009). The results of this study point to a relationship between conflict and violence, which were already expected since violence can be understood by the spouses as a strategy of conflict resolution (Falcke, Boeckel, Arpini \& Madalena, 2015).

Corroborating the existing literature, we observed that the higher the hierarchy in the family, the larger is the perpetration of violence by spouses. This can be explained to the extent that there is a power relationship in which each partner seeks to exercise greater control and have greater decision-making power, often claiming this status through violence (De Antoni, Martins-Teodoro \& Koller, 2009).

Among all these examined factors, we found that the variables that have greater explanatory power of violence committed by the wife was sexual abuse in childhood and the perception of conflict in family relationships. Experiencing sexual abuse in childhood often has an impact on adult life and can trigger problems in cognitive, affective and social development of the victim and still stands out as a risk factor for developing various psychopathologies (Borges \& Dell'Aglio, 2008; Habigzang, Koller, Azevedo \& Machado, 2005).

Sant'Anna and Baima (2008) observed in their study, with medical records of women victims of childhood sexual abuse, a characteristic symptomatology related to social and affective adaptation issues such as guilt, low self-esteem, anxiety, suicidal ideation, difficulty in making decisions, feelings of incapacity and failure, depression, insecurity and difficulty in trusting people. The authors also point out that maintaining the secret keeps the victim of abuse in vulnerability and coercion, since they do not ask for and therefore receive no help, which may be related to affective and adaptive issues, characterized especially by anxiety, insecurity, lack of trust in others and aggressiveness. This aggressiveness can lead to the perpetration of conjugal violence, when there conflict in the conjugal and family relationship.

How the family resolves their conflicts will provide relational patterns that can lead to new conflicts or new resolution strategies. Perceiving family conflicts is associated with the occurrence of emotional problems especially in childhood and adolescence (Cummings \& Davies, 2002; Wamboldt \& Wamboldt, 2000). In a study by Guimarães and Campos to approach the perception of violence of adolescents that study in public schools in Goiânia, they verified that the speeches of female adolescents is more permeated by the violence in family relations, while the male speech is more directed to a social view of violence. In this way, they report that difficulties on reflecting and dialoguing in the resolution of conflicts are factors that contribute to the use of violence, allowing the repetition of the early experiences of abuse and violence experienced in the family of origin.

For men, the greatest predictor of violence perpetrated by them was marital dissatisfaction. Unsatisfactory marital relationships can lead to divorce or separation and increase the risk of developing psychopathologies, being involved in car accidents, exposure to physical illness, attempted suicide, homicide or acts of violence (Braz, Dessen \& Silva, 2005). So the data from the present study corroborate previous research that associates dissatisfaction in the marital relationship 
with the occurrence of violence (DeMaris, 2000; Williams \& Frieze, 2005), in this case in the male population.

Although the data indicate that there was no significant difference in the perpetration of violence according to gender, the predictive variables of violence perpetrated by women seem to indicate a context of violence in a more situational way, in which, faced with a situation of conflict, they lean to the aggressive relationship model experienced in childhood. On the other hand, for men, violence seems to result from a more global dissatisfaction with the relationship as a whole, emerging as an ineffective strategy for resolving dissatisfaction.

\section{Final Considerations}

This study not only confirmed the association between different variables and conjugal violence that had already examined in previous studies, but also allowed us to identify those that had the greatest power for predicting its occurrence. Thus, we could verify how the phenomenon of violence in intimate relationships is complex and multidetermined, allowing us to reflect on the need for health professionals to have a comprehensive understanding, when working in the systems which attend to those who have experienced violence in childhood and can focus on intervention, helping to break the cycle of family violence.

Although the outline was broadened, considering a larger sum of interacting variables, the fact we had to leave out a series of other variables certainly limited the study. In any case, we believe that the more complex the models of interaction between variables, the greater will be the understanding on the phenomenon of conjugal violence In this sense,we suggest that future studies be carried out with the intention of testing theoretical models of interaction between the studied constructs, through modeling of structural equations, for example.

\section{References}

Alves, S. L. B., \& Diniz, M. N. F. (2005). "Eu digo não, ela diz sim": a violência conjugal no discurso masculino. Revista Brasileira de Enfermagem, 58(4), 387-392. doi:10.1590/S0034-71672005000400002.

Baptista, A. C. C. C. (2012). Estudo de caso de uma mulher sujeita a violência conjugal psicológica, com crenças de amor romântico e uma história de violência interparental. (Dissertação de Mestrado). ISPA - Instituto
Universitário. Retrieved from: http://repositorio. ispa.pt/bitstream/10400.12/2258/1/12678.pdf

Barreto, A. C., Bucher-Maluschke, J. S. N. F., Almeida, P. C., \& DeSouza, E. (2009). Desenvolvimento humano e violência de gênero: uma integração bioecológica. Psicologia: Reflexão e Crítica, 22(1), 8692. doi: 10.1590/S0102-79722009000100012.

Bhona, F. M. C., Lourenço, L. M., \& Brum, C. R. S. (2011). Violência Doméstica: Um estudo bibliométrico. Arquivos Brasileiros de Psicologia, 63(1), 1-110. Retrieved from: http:// pepsic.bvsalud.org/scielo.php?pid=S1809-52672011000100010\&script=sci_arttext

Blay, E. A. (2003). Violência contra a mulher e políticas públicas. Estudos avançados, 17(49), 87-98. doi: 10.1590/S0103-40142003000300006

Borges, J. L., \& Dell'Aglio, D. D. (2008). Relações entre abuso sexual na infância, transtorno de estresse pós-traumático (TEPT) e prejuízos cognitivos. Psicologia em Estudo, 13(2), 371-379. doi: 10.1590/ S1413-73722008000200020

Braz, M. P., Dessen, M. A., \& Silva, N. L. P. (2005). Relações conjugais e parentais: uma comparação entre famílias de classes sociais baixa e média. Psicologia: Reflexão e crítica, 18(2), 151-161. Retrieved from: http://www.scielo.br/pdf/prc/v18n2/27465.pdf

Calvete, E., Estévez, A., \& Corral, S. (2007). Intimate partner violence and depressive symptoms in women: Cognitive schemas as moderators and mediators. Behaviour research and therapy, 45(4), 791-804. doi: 10.1016/j.brat.2006.07.006

Crawford, E., \& Wright, M. O. D. (2007). The impact of childhood psychological maltreatment on interpersonal schemas and subsequent experiences of relationship aggression. Journal of Emotional Abuse, 7(2), 93-116. doi: 10.1300/J135v07n02_06

Cassepp-Borges, V., \& Teodoro, M. L. M. (2007). Propriedades psicométricas da versão brasileira da Escala Triangular do Amor de Sternberg. Psicologia: Reflexão e Crítica, 20(3), 513-522. doi: 10.1590/ S0102-79722007000300020

Cummings, E. M., \& Davies, P. T. (2002). Effects of marital conflict on children: Recent advances and emerging themes in process oriented-research. Journal of Child Psychology and Psychiatry, 43(1), 3163. doi: 10.1111/1469-7610.00003 
De Antoni, C., Martins-Teodoro, M. L., \& Koller, S. H. (2009). Coesão e hierarquia em famílias fisicamente abusivas. Universitas Psychologica, 8(2), 399-412. Retrieved from: http://www.scielo.org.co/pdf/ rups/v8n2/v8n2a08

DeMaris, A. (2000). Till Discord Do Us Part: The Role of Physical and Verbal Conflict in Union Disruption. Journal of Marriage and the Family, 62(3), 683-692. Retrieved from: http://www.jstor.org/ stable/1566789?seq=1\#page_scan_tab_contents

Dewes, J. O. (2013). Amostragem em Bola de Neve e Respondent-Driven Sampling: uma descrição dos métodos. Trabalho de Conclusão de Curso de Estatística. Porto Alegre, UFRGS. Retrieved from: http://hdl.handle.net/10183/93246 Acessed on: 15 of may 2017.

Dias, A. S. F., \& Neves, A. S. (2014). A constituição do vínculo conjugal violento: estudo de caso. Vínculo - Revista do NESME, 11(1), 8-15. Retrieved from: http://pepsic.bvsalud.org/pdf/vinculo/v11n1/ n1a03.pdf

Dias, A. R., Machado, C., Gonçalves, R. A., \& Manita, C. (2012). Repertórios interpretativos sobre o amor e as relações de intimidade de mulheres vítimas de violência: Amar e ser amado violentamente? Análise Psicológica, 30(1-2), 143-159. Retrieved from: http://www.scielo.gpeari.mctes.pt/scielo.php?pi$\mathrm{d}=$ S0870-82312012000100012\&script=sci_arttext

Falcke, D. (2003). Águas Passadas Não Movem Moinhos? As Experiências na Família de Origem como Preditoras da Qualidade do Relacionamento Conjugal (Tese de doutoramento). Universidade Federal do Rio Grande do Sul, Porto Alegre.

Falcke, D., Boeckel, M. G., Arpini, D., \& Madalena, M. (2015). Violência conjugal: Em briga de marido e mulher não se mete a colher? In: Wagner, A., Mossmann, C., \& Falcke, D. (Org). Viver a dois: Oportunidades e Desafios da Conjugalidade (1 $1^{\mathrm{a}} \mathrm{Ed}$.), (v. 1, pp. 79-100). São Leopoldo: Sinodal.

Falcke, D., Oliveira, D. Z., Rosa, L. W., \& Bentancur, M. (2009). Violência conjugal: um fenômeno interacional. Contextos Clínicos, 2(2), 81-90. Retrieved from: http://pepsic.bvsalud.org/scielo.php?script=sci_arttext\&pid $=$ S1983-34822009000200002

Gama, I. S., Bezerra-Filho, J. G., Silva, J. G., Vieira, L. J. E. S., \& Parente, E. O. (2014). Fatores associados à violência física denunciada por mulheres. Journal of Health \& Biological Sciences, 2(4), 168-175. doi: 10.12662/2317-3076jhbs. v2i4.105.p168-175.2014.

Gomes, N. P., Carvalho, M. R. S., Couto, T. M., \& Diniz, N. M. F. (2013). Violência conjugal e o atendimento da mulher na delegacia e no serviço de saúde. Revista baiana de enfermagem, 27(2), 146-153. Retrieved from: http://www.portalseer.ufba.br/index. php/enfermagem/article/view/6928

Gottman, J. M. (1994). What predicts divorce? The relationship between marital process and marital outcomes. Hillsdale: Lawrence Erlbaum

Grossi, M. (1998). Rimando amor e dor: reflexões sobre a violência no vínculo afetivo-conjugal. In: Pedro, J. M. \& Grossi, M. P. (Orgs.). Masculino, feminino, plural: gênero na interdisciplinaridade. (pp. 293-313). Florianópolis, Mulheres.

Guimarães, S. P., \& Campos, P. H. F. (2007). Norma social violenta: um estudo da representação social da violência em adolescentes. Psicologia: Reflexão e Crítica, 20(2), 188-196. doi: 10.1590/ S0102-79722007000200003

Habigzang, L. F., Koller, S. H., Azevedo, G. A., \& Machado, P. X. (2005). Abuso sexual infantil e dinâmica familiar: aspectos observados em processos jurídicos. Psicologia: teoria e pesquisa, 21(3), 341-348. doi: 10.1590/S0102-37722005000300011

Khosravi, Z., Attari, A., \& Rezaei, S. (2011). Intimate partner violence in relation to early maladaptive schemas in a group of outpatient Iranian women. Procedia-Social and Behavioral Sciences, 30, 13741377. doi: 10.1016/j.sbspro.2011.10.266

Lauer, R., Lauer, J., \& Kerr, S. (1990). The long-term marriage: perceptions of stability and satisfaction. International Journal of Aging and Human Development, 31(3), 189-195. doi: 10.2190/ H4X7-9DVX-W2N1-D3BF

Leite, M. T. S., Figueiredo, M. F. S., Dias, O. V., Vieira, M. A., Souza, L. P. S., \& Mendes, D. C. (2014). Ocorrência de violência contra a mulher nos diferentes ciclos de vida. Revista Latino-Americana de Enfermagem, 22(1), 85-92. doi: 10.1590/0104-1169.3186.2388

Lopes, S. M. P.C. (2008). Influências familiares na conjugalidade: o clima relacional na familia de origem, a satisfação conjugal e a proximidade conjugal. (Dissertação de Mestrado). Universidade de Lisboa, Faculdade de 
Psicologia e Ciências da Educação. Retrieved from: http://repositorio.ul.pt/handle/10451/720

Lovestad, S., \& Krantz, G. (2012). Men's and women's exposure and perpetration of partner violence: an epidemiological study from Sweden. BMC Public Health, 12:945. doi:10.1186/1471-2458-12-945

Marasca, A., Colossi P. M. \& Falcke, D. (2013). Violência conjugal e família de origem: uma revisão sistemática da literatura de 2006 a 2011. Temas em Psicologia, 21(1), 221-243. doi: 10.9788/TP2013.1-16

Metz, C., \& Razon, L. (2014). Marital violence: from child witness to adult offender. Psychology Applications \& Developments Advances. In: Psychology and Psychological Trends Series, (pp.319- 327).

Mendlowicz, M., \& Figueira, I. (2007). Transmissão intergeracional da violência familiar: o papel do estresse pós-traumático. Revista Brasileira de Psiquiatria, 29(1), 88-89. doi: 10.1590/S1516-44462007000100023

Miranda, M. P. M., De Paula, C. S. P., \& Bordin, I. A. (2010). Violência conjugal física contra a mulher na vida: prevalência e impacto imediato na saúde, trabalho e família. Revista Panamericana de Salud Pública, 27(4), 300-308. doi: 10.1590/S1020-49892010000400009

Moura, M. A. V., Netto, L. A., Leite, F. M. C., Lima, F. R. S, \& Teixeira, S. V. B. (2013). Mulheres que denunciam violência de gênero em uma Unidade de Polícia Pacificadora. Revista Eletrônica de Enfermagem, 15(3), 628-637. Retrieved from: http://www. revistas.ufg.br/index.php/fen/article/view/20286

Narciso, I., \& Costa, M. E. (1996). Amores satisfeitos, mas não perfeitos. Cadernos de Consulta Psicológica, 12,115-130. Retrieved from: http://repositorio -aberto.up.pt/bitstream/10216/15550/2/84570. pdf

Notarius, C., \& Markman, H. (1993). We can work it out - making sense of marital conflict. Nova York: Putnam's Sons.

Oliveira, J. B., Lima, M. C. P., Simão, M. O., Cavariani, M. B., Tucci, A. M., \& Corrêa, F. K. (2009). Violência entre parceiros íntimos e álcool: prevalência e fatores associados. Revista Panamericana de Salud Pública, 26(6), 494-501. doi: 10.1590/ S1020-49892009001200004

Oliveira, K. L. S. \& Gomes, R. (2011). Homens e violência conjugal: uma análise de estudos brasileiros.
Ciência \& Saúde Coletiva, 16(5), 01-13. doi: 10.1590/ S1413-81232011000500009

Paim, K., Madalena, M., \& Falcke, D. (2012). Esquemas iniciais desadaptativos na violência conjugal. Revista Brasileira de Terapias Cognitivas, 8(1), 31-39. Retrieved from: http:// pepsic.bvsalud.org/scielo.php?pid=S1808$-56872012000100005 \&$ script $=$ sci_arttext

Razera, J., Mosmann, C. P., \& Falcke, D. (2016). The Interface Between Quality and Violence in Marital Relationships. Paidéia (Ribeirão Preto), 26(63), 71-79.

Rijo, D., \& Pinto-Gouveia, J. (1999). A new instrument for the assessment of early maladaptive schemas. Poster presented to the Society for Psychotherapy Research 30th Annual Meeting, Braga.

Rosa, L. W. D., \& Falcke, D. (2014). Violência conjugal: compreendendo o fenômeno. Revista da SPAGESP, 15(1), 17-32. Retrieved from: http:// pepsic.bvsalud.org/scielo.php?script $=$ sci_arttext\& pid $=$ S1677-29702014000100003

Sant'Anna, P. A., \& Baima, A. P. D. S. (2008). Indicadores clínicos em psicoterapia com mulheres vítimas de abuso sexual. Psicologia: ciência e profissão, 28(4), 728-741.

Santos, A. C. W. S., \& Moré, C. L. O. O. (2011). Impacto da violência no sistema familiar de mulheres vítimas de agressão. Psicologia: Ciência e Profissão, 31(2), 220-235. doi: 10.1590/S1414-98932011000200003

Santos, L. C., Santos, K. M. M. S., Lima, L. S. R., Brito, L. S., Silva, Y. F., \& Gonçalves, H. D. A. (2014). A Violência Doméstica contra Mulher por Companheiro e a Lei Maria da Penha. Caderno de Graduação-Ciências Humanas e Sociais-UNIT, 2(1), 79-86. Retrieved from: https://periodicos.set.edu.br/index.php/ cadernohumanas/article/view/1259

Silva, J. G., Valadares, F. C., \& Souza, E. R. (2013). O desafio de compreender a consequência fatal da violência em dois municípios brasileiros. Interface Comunicação, Saúde, Educação, 17(46), 535-548. doi: 10.1590/S1414-32832013005000022

Spanier, G. B. (1976). Measuring Dyadic Adjustment: New Scales for Assessing the Quality of Marriage and Similar Dyads. Journal of Marriage and Family, 38(1), 15-28. doi: $10.2307 / 350547$

Sternberg, R. J. (1989). The Triangle of Love: Intimacy, Passion, Commitment. New York: Basic Books. 
Straus, M. A. (1990). The National Family Violence Surveys. In: Straus M. A. \& Gelles R. J. (Eds.), Physical violence in American families: risk factors and adaptations to violence in 8145 families (pp. 3-16). New Brunswick: Transaction Publishers.

Straus, M. A., Hamby, S. L., Boney-McCoy, S., \& Sugarman, D. B. (1996). The revised Conflict Tactics Scales (CTS2): Development and preliminary psychometric data. Journal of Family Issues, 17(3), 283-316. doi: 10.1177/019251396017003001

Straus, M. A. (2008). Dominance and symmetry in partner violence by male and female university students in 32 nations. Children and Youth Services Review, 30(10), 252-275. doi:10.1016/j. childyouth.2007.10.004

Straus, M. A. (2011). Gender symmetry and mutuality in perpetration of clinical-level partner violence: Empirical evidence and implications for prevention and treatment. Aggression and Violent Behavior, 16(4), 279-288. doi:10.1016/j.avb.2011.04.010

Teodoro, M. L. M., Allgayer, M., \& Land, B. (2009). Desenvolvimento e validade fatorial do Inventário do Clima Familiar (ICF) para adolescentes. Psicologia: Teoria e Prática, 11(3), 27-39. Retrieved from: http://pepsic.bvsalud.org/scielo.php?pid=S1516$-6872009000300004 \&$ script $=$ sci_arttext
Thornton, A. J., Graham-Kevan, N., \& Archer, J. (2010). Adaptive and Maladaptive Personality Traits as Predictors of Violent and Nonviolent Offending Behavior in Men and Women. Agressive Behavior, 36(3), 177-186. doi: 10.1002/ab.20340

Wamboldt, M. Z, \& Wamboldt, F. S. (2000). Role of the family in the onset and outcome of childhood disorders: Selected research findings. Journal of American Academy of Child Adolescent Psychiatry, 39(10), 12121219. doi: 10.1097/00004583-200010000-00006

Williams, S. L. \& Frieze, I. H. (2005). Patterns of Violent Relationships, Psychological Distress, and Marital Satisfaction in a National Sample of Men and Women. Sex Roles, 52(11-12), 771-784. doi: 10.1007/s11199-005-4198-4

Young, J. (2003). Terapia cognitiva para transtornos da personalidade: Uma abordagem focada em esquemas. Porto Alegre: Artmed.

Young, J., Klosko, J., \& Weishaar, M. (2008). Terapia do esquema: Guia de técnicas Cognitivo-comportamentais inovadoras. Porto Alegre: Artmed

Recebido em: 22/03/2016

Reformulado em: 22/03/2017

Aprovado em: 16/09/2017

Sobre as autoras:

Karla Rafaela Haack is a psychologist, $\mathrm{PhD}$ in Psychology from the Universidade do Vale do Rio dos Sinos (Unisinos). Member of the Family and Violence Research Center (NEFAV).

Email: krh.psi@gmail.com, ORCID 0000-0001-8566-3847

Juliana Pressi is a psychologist, Specializing in Psychological Assessment (Faccat), Specialist in Cognitive Behavioral Therapy and Scheme Therapy (Wainer Psychology).

Email: pressijuliana@gmail.com, ORCID 0000-0002-1111-8915.

Denise Falcke is a psychologist and holds a $\mathrm{PhD}$ from Pontifícia Universidade Católica do Rio Grande do Sul (PUCRS). Professor of Psychology at the Research Graduate Program in Clinical Psychology at Universidade do Vale do Rio dos Sinos (UNISINOS), Coordinator of the Family and Violence Research Center (NEFAV).

E-mail: dfalcke@unisinos.br, ORCID 0000-0002-4653-1216

Contato com as autoras:

Av. Unisinos, 950, Cristo Rei

São Leopoldo-RS, Brasil

CEP: 93022-750 